\title{
A COMPARISON OF THE SPECIFIC EFFECTS OF OESTRIOL AND OESTRADIOL ON THE UTERINE BODY AND CERVIX OF THE SPAYED RAT
}

\author{
F. D. JOHNSTONE, R. GULLEN AND G. YOUNGSON \\ Department of Physiology, Aberdeen University, and \\ Clinical Research Unit, Maternity Hospital, Aberdeen
}

(Received 29th March 1973)

\begin{abstract}
Summary. The theory that oestriol and oestradiol have specific patterns of effect on the lower and upper reproductive tracts was investigated in the spayed rat. At dose levels which produced similar increases in uterine wet weight, there was no difference in decrease in tensile strength of the cervix. From a review of the literature, it is suggested that oestriol may exert a pronounced effect on the cervix in late pregnancy, but not because of any specific 'polar' effect.
\end{abstract}

\section{INTRODUCTION}

In a series of experiments in the late 1950s, Puck \& Hübner (1956) and Puck, Korte \& Hübner (1957) claimed to show that oestradiol and oestriol had a specific 'biological polarity of effect', in that oestradiol acted mainly on the body of the uterus, and that oestriol, though possessing a weak action on the endometrium and myometrium, had a pronounced effect on the cervix and vagina. They concluded that 'oestriol should be used to influence the cervix and vagina when one does not want to influence the endometrium, for example in senile vaginitis and in dysmenorrhoea'. Overbeck \& de Visser (1958) confirmed this work in the spayed rat, and further support was given by Kusuda \& Matsumato (1963 and other studies referred to in that paper). The subject was reviewed by Merrill (1958). Borglin (1959) gave oestriol to seventy-five cases of uterovaginal prolapse preoperatively and concluded that there was only a slight endometrial response but a marked vaginal response. This polarity of effect has remained as a concept in gynaecology since then, and has recently been restated (Diczfalusy, 1967; Klopper, 1971).

It is of interest not only because of any possible therapeutic value which oestriol may have but also because of the suggestion that oestriol may be responsible for the specific changes of the cervix in late human pregnancy. A review of the original work, however, shows that the effects of the two oestrogens on the upper and lower reproductive tracts were often not quantified. It is known that there is a very great variation in response under different conditions of administration (see Emmens \& Martin, 1964 for a detailed review) and threshold doses and dose-response relationships may differ in the different tissues. Ideally, the effect on one tissue should be compared using doses of each 
oestrogen which produced an equivalent response on the other tissue. An attempt to do this was made in this study, the two parameters being increase in uterine wet weight and decrease in tensile strength of the cervix (Zarrow \& Yochim, 1961).

\section{MATERIALS AND METHODS}

Fifty rats of a closely bred Norwegian Hooded Lister strain were used, and were housed in groups of six to eight per cage under identical and controlled conditions of lighting, temperature and diet. Bilateral oophorectomy was performed on all animals when they were between 100 and 110 days old. Between 40 and 45 days after operation, a course of six daily intraperitoneal injections was started, each injection being given at 08.00 hours. Crystalline preparations of oestra-1,3,5(10)-triene-3,16 $\alpha, 17 \beta$-triol (oestriol) and oestra-1-3,5(10)-triene-3, $17 \beta$-diol (oestradiol) were used, with propylene glycol as solvent, the amount of fluid injected being kept constant at $0.4 \mathrm{ml} /$ day in all cases. Each animal was killed by being placed in an ether bath $28 \mathrm{hr}$ after the final injection. The uterus and cervix were removed, quickly trimmed of vagina and fatty tissue, blotted lightly and weighed to the nearest $0.1 \mathrm{mg}$ on a torsion balance. The cervix was then separated from the uterine horns in the manner described by Harkness \& Harkness (1959) and weighed.

The instrument used to measure cervical 'tenacity' was basically similar to that described by Harkness \& Harkness (1959). A small brass plate was drilled to allow two small needles to be inserted and attached by their points. A third needle, bent at the end, could be passed through the eyes of these needles. A hook on the top of the brass plate was connected by cord to a balance pan. This was suspended over a large perspex wheel which could rotate freely around a metal rod passed through its centre. A shallow groove around the circumference kept the cord in position. To make the measurement, a needle bent in the shape of a hook and fixed to a plate was passed through the cervix, and then through the other eye of the vertical needles. Weights were then added to the balance pan in a systematic manner according to a set routine, until the cervix was torn through the needles, the breaking weight generally being in the 1- to 2-kg range. An estimate of the 'tenacity' of the cervix was calculated as the weight ( $g$ ) necessary to break $1.0 \mathrm{mg}$ cervical tissue. Although this type of measurement has been referred to as tensile strength by other authors, tensile strength by definition is force per unit area and not force per unit weight. This is discussed by Zarrow \& Yochim (1961) who conclude that this type of measurement is valid for comparative studies where the same tissue is used.

\section{RESULTS}

The effects of six daily injections of $0.1 \mathrm{mg}, 0.67 \mathrm{mg}$ and $3.2 \mathrm{mg}$ of oestriol each in $0.4 \mathrm{ml}$ propylene glycol are shown in Table 1. Basal levels for five untreated rats are also shown. As expected, uterine and cervical wet weights increased with increasing amounts of oestriol and the tensile strength decreased. The effect of two treatment levels of oestradiol is also shown in Table 1. It can be seen that the mean uterine wet weight for the first oestradiol treatment group 
Table 1. A comparison of the effects of oestriol and oestradiol on the wet weights of the uterus and cervix and the tensile strength of the cervix of spayed rats

\begin{tabular}{l|c|c|c|c}
\hline & $\begin{array}{c}\text { No. of } \\
\text { animals }\end{array}$ & $\begin{array}{c}\text { Uterine wet } \\
w t \pm S . D .\end{array}$ & $\begin{array}{c}\text { Cervical wet } \\
w t \pm S . D . \\
(\mathrm{mg})\end{array}$ & $\begin{array}{c}\text { Tensile strength } \pm \\
\text { S.D. (breaking force } \\
\text { in g/mg cervical tissue) }\end{array}$ \\
\hline BASAL & 5 & $102 \cdot 5 \pm 15 \cdot 6$ & $24 \cdot 0 \pm 2 \cdot 5$ & $44 \cdot 8 \pm 4 \cdot 7$ \\
\hline TREATMENT GROuPs & & & & \\
Oestriol 0.1 mg daily & 9 & $143 \cdot 7 \pm 18 \cdot 2$ & $34 \cdot 8 \pm 3 \cdot 9$ & $35 \cdot 2 \pm 3 \cdot 9$ \\
Oestriol 0.67 mg daily & 8 & $188 \cdot 8 \pm 18 \cdot 4$ & $43 \cdot 0 \pm 2 \cdot 4$ & $30 \cdot 5 \pm 5 \cdot 8$ \\
Oestriol 3.2 mg daily & 8 & $368 \cdot 5 \pm 91 \cdot 5$ & $61 \cdot 8 \pm 7 \cdot 3$ & $18 \cdot 8 \pm 4 \cdot 5$ \\
Oestradiol 1 g daily & 8 & $193 \cdot 8 \pm 20 \cdot 5$ & $41 \cdot 3 \pm 6 \cdot 8$ & $30 \cdot 6 \pm 3 \cdot 29$ \\
Oestradiol 8 g daily & 8 & $219 \cdot 0 \pm 29 \cdot 6$ & $45 \cdot 6 \pm 3 \cdot 3$ & $27 \cdot 9 \pm 4 \cdot 6$ \\
\hline
\end{tabular}

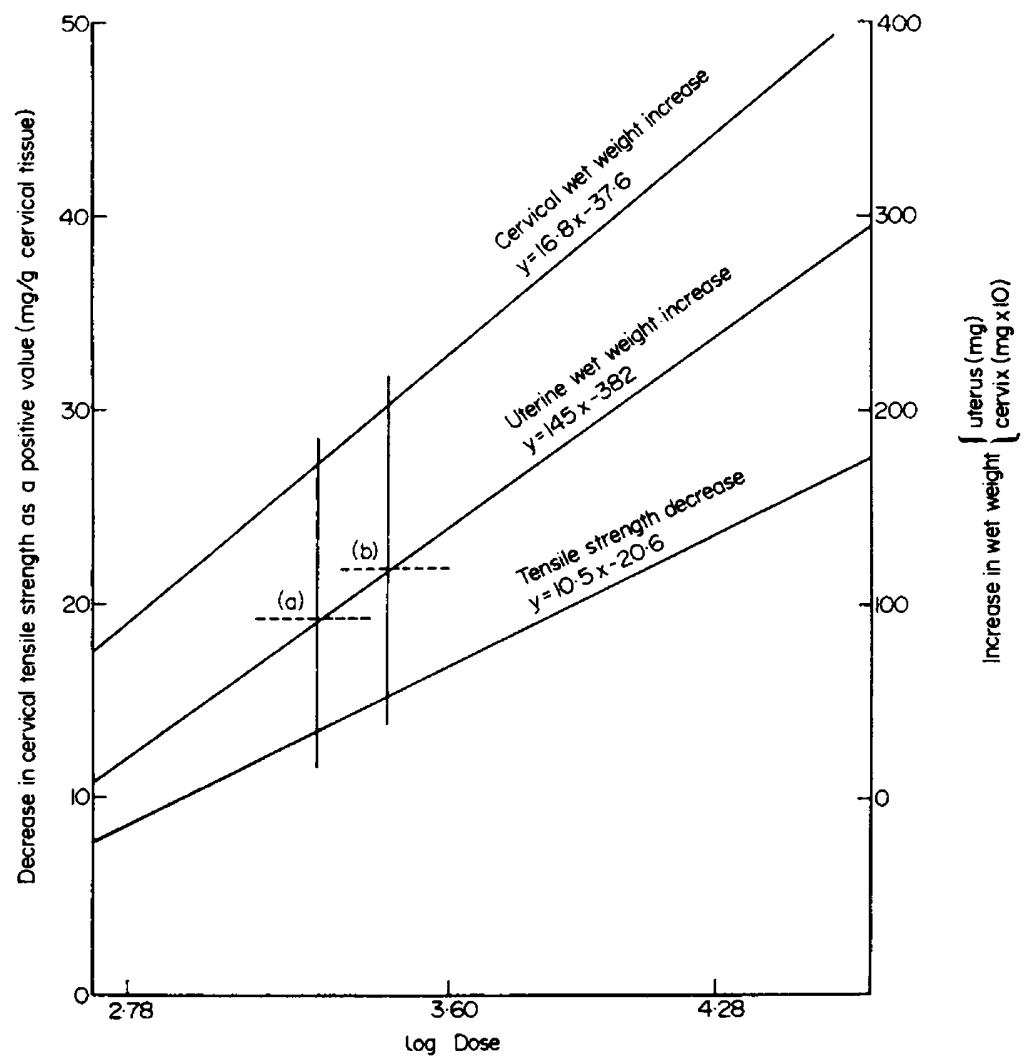

TExT-Fig. 1. Linear regression values for the increase in cervical wet weight and uterine wet weight and the decrease in cervical tensile strength in oestriol-treated groups of spayed rats. 
( $1 \mu \mathrm{g}$ daily) is almost identical to that for the second oestriol treatment group $(670 \mu \mathrm{g}$ daily). In other words, by this method of administration, these are equivalent doses in their effect on the upper reproductive tract. The effect of these two dose levels of oestrogens on the lower reproductive tract-the cervical weight and cervical tensile strength-is also identical $(P>0.95)$.

The results for oestriol were expressed as linear regression equations of the increase in uterine wet weight over basal levels, the increase of cervical wet weight, and the decrease in tensile strength expressed as a positive value, each against log. total dose (Text-fig. 1). The correlation coefficients were $0 \cdot 82$, 0.89 and 0.79 respectively. When the known values for increase in uterine wet weight for the $1 \mu \mathrm{g}$-oestradiol treatment group are projected, expected values for oestriol-treated rats were calculated to be 31.4 and $29.6 \mathrm{~g} / \mathrm{mg}$ cervical tissue respectively for tensile strength and 41.2 and $44.2 \mathrm{mg}$ respectively for cervical weight. The values actually found in the $1 \mu \mathrm{g}$ and $8 \mu \mathrm{g}$ oestradiol-treated groups $(30.6$ and $27.9 \mathrm{~g} / \mathrm{mg}$ cervical tissue respectively for tensile strength and 41.3 and 45.6 respectively for cervical weight) were similar to the values expected for oestriol-treated rats. It was, in fact, the oestradiol-treated groups which showed a marginally and not significantly greater oestrogenic effect. Thus, for oestriol and oestradiol, no significant difference was found in the effect on the cervical tensile strength when the same effective dose for increase in uterine wet weight was considered.

\section{DISGUSSION}

In this study, there was no systematic attempt to investigate relative potencies or dose-response effects but merely to identify a similar increase in uterine wet weight produced by the two oestrogens. When these 'equivalent' doses were considered, the decrease in cervical tensile strength appeared to be the same for both categories. This is at variance with the many studies referred to above.

As 'equivalent' doses were not considered in the earlier studies, an incorrect impression may have been obtained because of the possibly differing doseresponse relationships of different tissues.

The finding does not, however, necessarily contradict the suggestion that oestriol may be responsible for the cervical changes of late human pregnancy, although it does alter the explanation. Thus, it has been known for some time that when responses in the vagina and uterus in the first $6 \mathrm{hr}$ are studied, oestriol given parenterally has a similar potency to oestradiol. This is true for example for the uptake of water (Szego, 1950; Hisaw, 1959; Haskins \& Hebel, 1970) and the increase in incorporation of uridine into RNA (Hamilton, 1963; Miller \& Emmens, 1967). The action of oestriol, however, has been shown to be short-lived compared with that of oestradiol (Miller, 1969). Oestriol, therefore, has a weak uterotrophic action in tests employing daily or single injections (see Rubin, Dorfman, Black \& Dorfman, 1951; Overbeck \& de Visser, 1958) but Miller (1969) found that, in the mouse, oestriol given every $4 \mathrm{hr}$ elicited as much growth in the uterus and vagina as did oestradiol. He therefore concluded that oestriol and oestradiol acted on the same sites in the uterus and vagina, and possibly initially with the same potency. Differences in response 
were found after single or daily injections because of the differences in retention of oestriol and oestradiol by the target organ. As oestriol is produced continuously in human pregnancy, this explanation does not contradict the idea that oestriol may have a pronounced effect on the cervix but if it does do so, it will be owing to its inherent oestrogenic potency and the amounts involved rather than to any specific effect.

In conclusion, this study has shown that, in the rat, as far as oestriol and oestradiol are concerned, there is no difference in their effect on decrease in cervical tensile strength when the same effective doses for increase in uterine wet weight are considered. It does not support the concept that oestriol and oestradiol have specific patterns of effect on the reproductive tract.

\section{ACKNOWLEDGMENTS}

We are grateful to the other medical students who assisted with a pilot experiment, to Dr A. Klopper for advice, and to Professor J. L. Malcolm and Professor G. R. Kelman for providing the facilities.

\section{REFERENCES}

Borglin, N. E. (1959) Effect of oestriol on the female genital tract. Acta obstet. gynec. scand. $38,108$. Diczfalusy, E. (1967) Observations. In Fetal Homeostasis, Vol. 2, p. 617. Ed. R. M. Wynn. New York Academy of Sciences, New York.

Emmens, C. W. \& Martin, L. (1964) Estrogens. In Methods of Hormone Research, Vol. 3, Chap. 1. Ed. R. I. Dorfman. Academic Press, New York.

Hamilton, T. H. (1963) Isotopic studies on oestrogen induced acceleration of ribonucleic acid and protein synthesis. Proc. natn. Acad. Sci. U.S.A. 49, 373.

HARKness, M. L. R. \& Harkness, R. D. (1959) Changes in the physical properties of the uterine cervix of the rat during pregnancy. 7. Physiol., Lond. 148, 524.

Haskins, A. L. \& Hebel, J. R. (1970) Estrogenic potential of estriol-a comparison of estrone, estradiol and estriol in aqueous and lipid solvents with bioassay. Am. 7. Obstet. Gynec. 106, 202.

Hisaw, F. L. (1959) Comparative effectiveness of estrogens on fluid inhibition and growth of the rat uterus. Endocrinology, 64, 276.

Klopper, A. (1971) The assessment of placental function in clinical practice. In Endocrinology of Pregnancy, p. 342. Eds. F. Fuchs and A. Klopper. Harper \& Row, London.

Kusuda, M. \& Matsumato, M. (1963) Effects of estriol on the female genital tract and its clinical applications. Kyushu 7. med. Sci. 14, 1.

Merrill, R. C. (1958) Estriol-a review. Physiol. Rev. 38, 463.

Miller, B. G. (1969) The relative potencies of oestriol, oestradiol, and oestrone on the uterus and vagina of the mouse. 7. Endocr. 43, 563.

Miller, B. G. \& Emmens, C. W. (1967) The incorporation of tritiated uridine in the genital tract of the oestrogen-treated mouse. 7 . Endocr. 39, 473.

Overbeck, G. A. \& De Visser, J. (1958) A comparison of oestriol and oestradiol in the female rat. Acta endocr., Copenh. 27, 73.

Puck, A. \& Hübner, K. A. (1956) Die Wirkungen des Oestriols auf Uterus und Vagina des Kaninchens und Meerschweinchens und auf die Symphyse des Meerschweinchens. Acta endocr., Copenh. 22, 191.

Puck, A., Korte, W. \& Hübner, K. A. (1957) Effects of oestriol on the body of the uterus, uterine cervix and vagina of women; studies with large $(30 \mathrm{mg})$ and minimal $(50 \mu \mathrm{g})$ doses. Dt. med. Wschr. 44, 160.

Rubin, B. L., Dorfman, A. S., Black, L. \& Dorfman, R. I. (1951) Bioassay of estrogens using the mouse uterine response. Endocrinology, 49, 429.

Szego, C. M. (1950) Relative effectiveness of natural estrogens in stimulating early uterine growth. Fedn Proc. Fedn Am. Socs exp. Biol. 9, 124.

ZarRow, M. X. \& Yochim, J. (1961) Dilation of the uterine cervix of the rat and accompanying changes during the estrous cycle, pregnancy and following treatment with oestradiol, progesterone and relaxin. Endocrinology, 69, 292. 